\title{
EVALUASI TINGKAT KEPUASAN PASIEN TERHADAP PELAYANAN KEFARMASIAN DI KLINIK X MENGGUNAKAN APLIKASI E-SERVQUAL BERBASIS WEB
}

\author{
Leonov Rianto ${ }^{1}$, Gilang Al'Qarana ${ }^{2}$, Alifa Sabrina ${ }^{3}$ \\ 1,2,3 Akademi Farmasi IKIFA \\ Email Korespondensi : leonovrianto@ikifa.ac.id
}

\begin{abstract}
ABSTRAK
Sebagai upaya dalam meningkatkan kualitas pelayanan, kepuasan pasien dapat diukur dengan metode SERVQUAL (SERVICE QUALITY) dengan cara membuat survey penilaian kepuasan pelanggan secara komperhensif bagi pelayanan di bidang barang dan jasa yang mengutamakan pelayanan kefarmasian. Analisis kepuasan pelanggan dilakukan berdasarkan lima dimensi kualitas layanan, yakni responsiveness, reability, assurance, empathy, dan tangible. Rumusan permasalahan dalam penelitian ini ingin mengetahui bagaimana kepuasan pasien terhadap pelayanan kefarmasian di klinik X. Tujuan dari penelitian ini adalah untuk mengetahui gambaran kepuasan pasien terhadap pelayanan kefarmasian di klinik X. Menggunakan metode deskriptif kuantitatif untuk mengetahui tingkat kepuasan pasien terhadap pelayanan kefarmasian menggunakan kuisioner sebagai instrumen penelitian. Data kunjungan pasien berobat pada 3 bulan awal tahun 2018 pada bulan Januari 2.970 pasien, Februari 2.868 pasien, dan bulan Maret 3.304 pasien. Bedasarkan pada data yang telah direkapitulasi secara sistem oleh aplikasi e-SERVQUAL berbasis web dan telah diuji validitasnya, maka persentase tiap variabel merata pada kisaran $70 \%$, pada dimensi sikap dan penampilan di peroleh persentase $71.88 \%$ pasien menyatakan puas, pada dimensi keandalan $72.70 \%$ pasien puas, pada dimensi waktu menunggu obat yaitu $71.30 \%$ pasien puas, pada dimensi jaminan $72.88 \%$ pasien menyatakan puas, pada dimensi empati pasien puas sebesar $70.33 \%$, pada dimensi sarana dan fasilitas pasien puas sebesar 72,20\%. Berdasarkan hasil penelitian dapat disimpulkan bahwa tingkat kepuasan pasien terhadap pelayanan kefarmasian yang dilihat pada enam dimensi dengan menggunakan aplikasi $e$ SERVQUAL dirancang secara khusus untuk dapat menerima dan merekap jawaban dari kuisioner yang telah diisi oleh pasien, diperoleh hasil bahwa dimensi keandalan, waktu tunggu resep, empati serta sarana dan fasilitas dirasa penting untuk diperhatikan. Selain itu untuk dimensi jaminan dan sikap \& penampilan dirasa sangat penting untuk menjadi prioritas dalam pelayanan kefarmasian di Klinik X.
\end{abstract}

Kata Kunci : Kepuasan, Klinik, Pelayanan, Aplikasi 


\title{
EVALUATION OF PATIENT SATISFACTION LEVELS ON PHARMACEUTICAL SERVICES IN CLINIC X USING WEB- BASED E-SERVQUAL APPLICATIONS
}

\begin{abstract}
As an effort to improve service quality, patient satisfaction can be measured by the SERVQUAL (SERVICE QUALITY) method by making a comprehensive customer satisfaction assessment survey for services on goods and services that prioritize pharmaceutical services. Analysis of customer satisfaction based on five dimensions of service quality, including responsiveness, reliability, assurance, empathy, and tangibility. The problems in this study want to know about patient satisfaction with pharmacy services in clinic $X$. The purpose of this study is to find images of patient satisfaction with pharmacy services in clinic X. Using quantitative descriptive methods to determine the level of patient satisfaction with pharmacy services using a questionnaire as a research instrument. Data on patient visits for treatment at 3 months beginning in 2018, with details of January 2,970 patients, February 2,868 patients, and March 3,304 patients. Based on the data that has been recapitulated systematically by the web-based e-SERVQUAL application and has been tested for validity, the percentage of each variable is evenly in the range of $70 \%$, on the dimensions of attitude and appearance states that the patient is satisfied by $71.88 \%$, on the reliability dimension states the patient is satisfied at $72.70 \%$, on the dimension of waiting time the drug states that the patient is satisfied by $71.30 \%$, on the guarantee dimension states the patient is satisfied by $72.88 \%$, on the empathy dimension states the patient is satisfied by $70.33 \%$, on the dimensions of facilities and infrastructure states the patient is satisfied by $72.20 \%$. Based on the results of the study it can be concluded that the level of patient satisfaction with pharmaceutical services seen in the six dimensions using the e-SERVQUAL application is specifically designed to be able to receive and recap answers from questionnaires that have been filled out by patients, the results obtained are the dimensions of reliability, waiting time for prescriptions, empathy and facilities and facilities are important to be observed. In addition, for the dimensions of guarantee and attitude \& appearance it is very important to be a priority in pharmaceutical services at Clinic $X$.
\end{abstract}

Keywords : satisfaction, clinic, service, application.

\section{PENDAHULUAN}

Menurut Munizu (2011) di era globalisasi saat ini persaingan usaha semakin ketat sehingga menjadikan dunia semakin sempit karena perusahaan semakin keras dalam memperebutkan konsumen. Untuk memenangkan persaingan perusahaan harus mampu memberikan kepuasan kepada pelanggannya dengan memberikan pelayanan kefarmasian yang baik (Jurnal Manajemen dan 


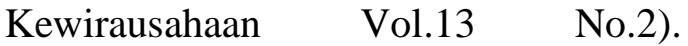
Pelayanan kefarmasian merupakan salah satu aspek yang sangat penting dalam pelayanan kesehatan di klinik X. Semakin baik tingkat pelayanan kefarmasian akan mempengaruhi tingkat kepuasan pasien. Pasien merasa puas apabila pelayanan kesehatan yang diperoleh seperti apa yang diharapkan. Standar pelayanan kefarmasian merupakan pedoman bagi tenaga kefarmasian dalam menyelenggarakan pelayanan kefarmasian. Peraturan Pemerintah Nomor 51 Tahun 2009 tentang Pekerjaan Kefarmasian menyatakan standar pelayanan kefarmasian di apotek meliputi pengelolaan sediaan farmasi dan pelayanan farmasi klinik.

Pelayanan kefarmasian adalah suatu pelayanan yang berkaitan dengan Sediaan Farmasi dengan maksud mencapai hasil yang pasti untuk meningkatkan mutu kehidupan pasien. Standar pelayanan kefarmasian adalah tolok ukur yang dipergunakan sebagai pedoman bagi tenaga kefarmasian dalam menyelenggarakan pelayanan kefarmasian. Ada beberapa metode yang bisa dipergunakan setiap perusahaan untuk mengukur dan memantau kepuasan konsumennya dan konsumen pesaing. Salah satunya adalah menggunakan Survei Kepuasan Konsumen.

Untuk mengukur kepuasan pasien di klinik X sebagai upaya dalam meningkatkan kualitas pelayanan, kepuasan pasien dapat di ukur dengan metode SERVQUAL (SERVICE
QUALITY) dengan cara membuat survei penilaian kepuasan pelanggan secara komperhensif bagi pelayanan di bidang barang dan jasa yang mengutamakan pelayanan kefarmasian. Analisis kepuasan pelanggan di lakukan berdasarkan lima dimensi kualitas layanan, yakni responsiveness, reability, assurance, empathy, dan tangible (Tjiptono, 2016). Menurut data yang didapat dari divisi customer care di klinik X menunjukan bahwa kunjungan pasien berobat pada 3 bulan awal tahun 2018 pada Januari 2.970 pasien, Februari 2.868 pasien, dan Maret 3.304 pasien. Dari data tersebut dapat dilihat bahwa jumlah kunjungan pasien klinik X dalam 3 bulan diawal tahun 2018 sangat bervariasi.

Pemanfaatan teknologi informasi saat ini telah menjadi keharusan dalam mendukung pekerjaan manusia. Oleh sebab itu, pada penelitian ini penulis menggunakan aplikasi e-SERVQUAL dalam mengolah data kuisioner yang diberikan kepada pasien di klinik $\mathrm{X}$ periode Februari-September 2018. Dengan memanfaatkan aplikasi ini, diharapkan hasil yang didapat selama penelitian lebih objektif dan akurat, serta dapat direkap secara realtime.

\section{METODE PENELITIAN}

Penelitian ini menggunakan metode deskriptif kuantitatif untuk mengetahui tingkat kepuasan pasien terhadap pelayanan kefarmasian di klinik $\mathrm{X}$. Variabel yang digunakan diantaranya adalah pelayanan kefarmasian, meliputi: Sikap dan penampilan, keandalan, 
waktu tunggu resep, jaminan, empati, sarana dan fasilitas.

\section{Definisi Operasional}

Tabel I. Definisi Operasional

\begin{tabular}{lll}
\hline No & \multicolumn{1}{c}{ Variabel } & \multicolumn{1}{c}{ Definisi } \\
\hline 1. & Sikap dan Penampilan & $\begin{array}{l}\text { Pelayanan yang memuaskan seperti; kesopanan, ramah, } \\
\text { murah senyum, penampilan yang rapih bersih dan } \\
\text { wangi dalam melayani pasien }\end{array}$ \\
\hline 2. & Keandalan & $\begin{array}{l}\text { Kemampuan untuk memberikan pelayanan yang } \\
\text { dijanjikan dengan terpercaya dan akurat. }\end{array}$ \\
\hline 3. & Waktu Tunggu Resep & $\begin{array}{l}\text { Lamanya waktu dalam melayani resep } \\
\text { Non racikan } \\
5-15 \text { menit dan Racikan maksimal 30 menit. }\end{array}$ \\
\hline 4. & Jaminan & $\begin{array}{l}\text { Meliputi kompetensi, kesopanan, kredibilitas, dan } \\
\text { keamanan yang memberikan rasa percaya pada pasien. }\end{array}$ \\
\hline 5. & Empati & $\begin{array}{l}\text { Rasa peduli memberikan perhatian secara individual } \\
\text { kepada pasien. }\end{array}$ \\
\hline 6. & Sarana Dan Fasilitas & $\begin{array}{l}\text { Kenyamanan, kebersihan ruang tunggu dan fasilitas } \\
\text { yang ada di Klinik Sapta Mitra. }\end{array}$ \\
\hline
\end{tabular}

Dengan menggunakan skala ordinal dan kriteria hasil sebagai berikut :

Tabel II. Rentang Skala Kepuasan dan Harapan

\begin{tabular}{|l|l|l|}
\hline Interval & Kepuasan & Harapan \\
\hline $81 \%-100 \%$ & Sangat Puas & Sangat Penting \\
\hline $61 \%-80 \%$ & Puas & Penting \\
\hline $41 \%-60 \%$ & Cukup Puas & Cukup Penting \\
\hline $21 \%-40 \%$ & Kurang Puas & Kurang Penting \\
\hline $0 \%-20 \%$ & Tidak Puas & Tidak Penting \\
\hline
\end{tabular}

Tabel III. Tingkat Kepuasan

\begin{tabular}{|c|c|}
\hline Nilai Korelasi & Kepuasan \\
\hline $0.800 \mathrm{~s} / \mathrm{d} 1.000$ & Tinggi \\
\hline $0.600 \mathrm{~s} / \mathrm{d} 0.799$ & Cukup \\
\hline $0.400 \mathrm{~s} / \mathrm{d} 0.599$ & Agak rendah \\
\hline $0.200 \mathrm{~s} / \mathrm{d} 0.399$ & Rendah \\
\hline $0.000 \mathrm{~s} / \mathrm{d} 0.199$ & Sangat rendah \\
\hline
\end{tabular}




\section{Jenis Penelitian}

Jenis penelitian ini adalah penelitian non eksperimen untuk mengetahui suatu gambaran dari populasi dan sampel.

\section{Lokasi dan Waktu}

Penelitian ini di lakukan di klinik X di Wilayah Jakarta Timur pada bulan Februari-September 2018.

\begin{abstract}
Alat dan Bahan
Alat dan bahan yang digunakan untuk penelitian ini adalah domain website, server hosting website, dan gadget. Alat tersebut digunakan untuk mengetahui gambaran dimensi-dimensi kualitas pelayanan kefarmasian yang diharapkan, dianggap penting dan yang memiliki kinerja cukup baik menurut model kualitas pelayanan
\end{abstract} (SERVQUAL) di Klinik X.

\section{Langkah Kerja}

a. Mempersiapkan domain website dan server hosting untuk aplikasi $e$ SERVQUAL.

b. Penyebaran kuisioner validasi kepada 30 responden melalui aplikasi $e$ SERVQUAL.

c. Mengolah data validasi kuesioner.

d. Penyebaran kuisioner yang sudah valid kepada 100 responden sampel melalui aplikasi e-SERVQUAL.

e. Pengisian kuesioner oleh responden.

f. Data yang telah di isi responden direkap melalui fitur laporan di aplikasi $e$-SERVQUAL.

g. Mengolah hasil data yang telah diperoleh.

h. Membahas hasil penelitian dan menyajikan data.

\section{Populasi dan Sampel}

Populasi dalam penelitian ini adalah pasien yang datang berkunjung ke klinik X. Sampel dalam penelitian ini adalah 100 pasien yang sudah di hitung menurut perhitungan sesuai rumus Slovin (Riduan, 2011, p.65).

$$
n=\frac{N}{N \cdot d^{2}+1}
$$

$n n=$ Jumlah Sampel

$N N=$ Jumlah Populasi (Jumlah pasien per hari dalam 3 bulan terakhir 102 resep) $X$ jumlah hari dalam 3 bulan (90 hari)

$d d=$ Presisi yang ditetapkan $(10 \%)$

$n=\frac{9180}{9180 .(0,1)^{2}+1}$

$n=98,922 \sim 100$

Jadi, jumlah sampel yang digunakan dari hasil perhitungan diatas dengan jumlah sampel telah diketahui adalah sebanyak 100 pasien.

Kriteria sampel meliputi kriteria inklusi dan kriteria eksklusi :

a. Kriteria Inklusi

Pasien yang mendapat resep dan menebus resep di klinik $X$ serta memiliki gadget atau perangkat yang dapat digunakan untuk mengakses internet.

b. Kriteria Eksklusi

Pasien yang tidak bersedia mengisi kuesioner.

\section{Analisis Data}

Analisis data yang dilakukan dalam penelitian ini untuk mengetahui tingkat kepuasan terhadap kualitas pelayanan:

a. Analisis statistik deskriptif dilakukan untuk memperoleh nilai pelayanan berdasarkan persentase 
kumulatif tingkat kepuasan dan harapan pasien.

b. Analisa kuantitatif indeks kualitas pelayanan untuk mengetahui kedudukan kepuasan pelanggan terhadap pelayanan farmasi di Klinik X. Indeks kepuasan pelanggan dapat analisa berdasarkan model Weight Servqual.

c. Analisis kuantitatif terhadap kualitas jasa yang diniliai pada lima dimensi, yaitu: sikap dan penampilan, keandalan, waktu Tunggu Resep, jaminan, empati, sarana dan fasilitas.

d. Analisis kuantitatif untuk mengetahui kesenjangan antara harapan pasien akan kualitas pelayanan dengan pelayanan yang dirasakannya terhadap pelayanan farmasi di Klinik X.

Kesenjangan menggambarkan selisih (gap) antara persepsi pelanggan terhadap pelayanan yang diberikan dengan harapan pasien. Angka negative akan menunjukkan bahwa harapan pelanggan tidak terpenuhi sedangkan angka positif menunjukkan bahwa harapan pasien terpenuhi. Rumusnya adalah sebagai berikut:

$$
G=P-E G=P-E
$$

Dimana :

$G G=$ Kesenjangan $($ gap $)$

$P P=$ Persepsi pasien terhadap pelayanan

$$
\text { E } \quad E=\text { Harapan pasien terhadap }
$$
pelayanan

$\mathrm{F}$

\section{HASIL DAN PEMBAHASAN \\ Penerapan Aplikasi e-SERVQUAL}

Aplikasi e-SERVQUAL dirancang secara khusus untuk dapat menerima dan merekap jawaban dari kuisioner yang telah diisi oleh responden. Aplikasi ini mudah digunakan dikarenakan dapat diakses diluar wilayah klinik $X$. Jika menggunakan kuisioner cetak, responden wajib mengisi ditempat dan kemudian mengumpulkan kembali pada saat itu juga. Melalui aplikasi e-SERVQUAL, responden dapat mengisi kuisioner kapanpun dan dimanapun ia berada. Sekalipun telah sampai dirumahnya, karena aplikasi yang diterapkan terkoneksi dengan jaringan internet. Dengan harapan, responden dapat mengisi kuisioner tidak terburu-buru dan mampu memberikan penilaian secara objektif.

Tabel IV. Tabel Hasil Uji Validitas

\begin{tabular}{|l|l|l|c|}
\hline Butir Soal Nomor & \multicolumn{1}{|c|}{ rhitung } & \multicolumn{1}{|c|}{ rtabel } & Keterangan \\
\hline 1 & 0,874 & 0,361 & VALID \\
\hline 2 & 0,940 & 0,361 & VALID \\
\hline 3 & 0,895 & 0,361 & VALID \\
\hline 4 & 0,905 & 0,361 & VALID \\
\hline 5 & 0,822 & 0,361 & VALID \\
\hline 6 & 0,914 & 0,361 & VALID \\
\hline 7 & 0,869 & 0,361 & VALID \\
\hline
\end{tabular}




\begin{tabular}{|l|l|l|l|}
\hline 8 & 0,874 & 0,361 & VALID \\
\hline 9 & 0,940 & 0,361 & VALID \\
\hline 10 & 0,765 & 0,361 & VALID \\
\hline 11 & 0,842 & 0,361 & VALID \\
\hline 12 & 0,847 & 0,361 & VALID \\
\hline 13 & 0,684 & 0,361 & VALID \\
\hline 14 & 0,805 & 0,361 & VALID \\
\hline 15 & 0,790 & 0,361 & VALID \\
\hline 16 & 0,735 & 0,361 & VALID \\
\hline 17 & 0,895 & 0,361 & VALID \\
\hline 18 & 0,905 & 0,361 & VALID \\
\hline 19 & 0,882 & 0,361 & VALID \\
\hline 20 & 0,914 & 0,361 & VALID \\
\hline 21 & 0,778 & 0,361 & VALID \\
\hline 22 & 0,815 & 0,361 & VALID \\
\hline
\end{tabular}

Hasil Uji Reabilitas

Case Processing Summary

\begin{tabular}{|ll|r|r|}
\hline & N & \multicolumn{1}{|c|}{$\%$} \\
\hline Cases & Valid & 30 & 100.0 \\
& Excluded $^{\mathrm{a}}$ & 0 & .0 \\
& Total & 30 & 100.0 \\
\hline
\end{tabular}

a. Listwise deletion based on all variabels in the procedure.

Reliability Statistics

\begin{tabular}{|r|r|}
\hline \multicolumn{1}{|c|}{$\begin{array}{c}\text { Cronbach's } \\
\text { Alpha }\end{array}$} & N of Items \\
\hline .981 & 22 \\
\hline
\end{tabular}

Gambar 1. Tampilan Aplikasi E-SERVQUAL menu pengisian kuisioner

\section{Menu Pelaporan Aplikasi $e-S E R V Q U A L$}

Dengan menggunakan aplikasi ini, maka data yang didapat langsung tersimpan kedalam basis data langsung setelah responden melakukan klik SUBMIT pada akhir dari kuisioner. Dengan pelaporan yang bersifat realtime ini, maka dapat dipastikan semua penilaian yang masuk kedalam sistem akan langsung diproses dan dapat dilihat hasil perekapan maupun rangkumannya seperti apa. Dengan begitu, baik peneliti maupun 
pimpinan klinik $\mathrm{X}$ dapat melihat gambaran umum hasil dari penilaian pasien terhadap kepuasan pelayanan kefarmasian yang ada di klinik X. Hasil dari aplikasi ini pun dapat diunduh dalam format csv (comma separated values) dan diteliti lebih lanjut oleh tim peneliti menggunakan metodologi yang telah ditentukan.

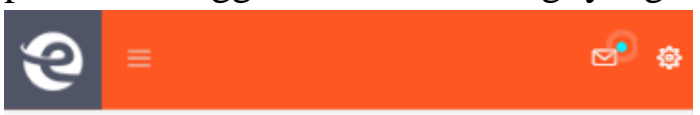

Laporan e-SERVQUAL

Laporan dan Backup

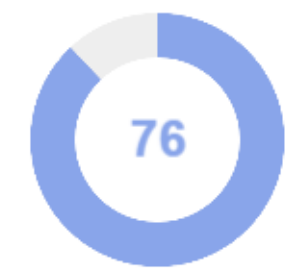

Sikap \& Penampilan

$$
\begin{array}{l|l}
\text { Cek Detail } & \text { Backup }
\end{array}
$$

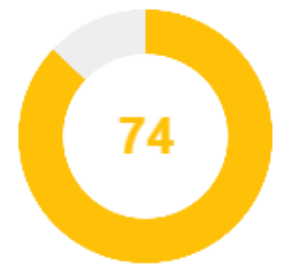

Keandalan

$$
\begin{array}{l|l}
\text { Cek Detail } & \text { Backup }
\end{array}
$$

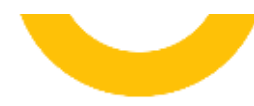

Keandalan
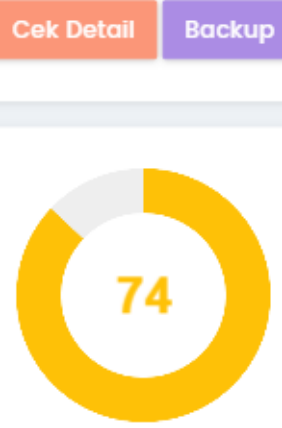

Waktu Tunggu
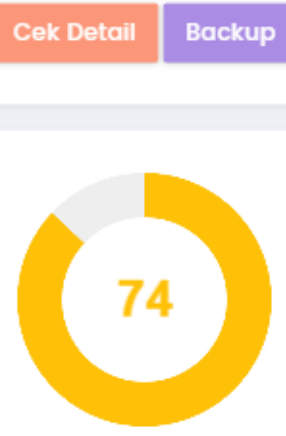

Jaminan

Cek Detail $\quad$ Backup

Gambar 2. Tampilan Aplikasi E-SERVQUAL menu pelaporan

\section{Uji Validitas Kuesioner}

Setelah dilakukan uji validitas pada 30 responden kuesioner dinyatakan valid apabila $r_{\text {hitung }}$ lebih besar dari $r_{\text {tabel }}$ $(0,361)$ dari data yang didapat hasil dari 22 butir pertanyaan kuesioner adalah Tabel V. Usia Pasien

\begin{tabular}{|c|c|}
\hline Usia (tahun) & Jumlah (orang) \\
\hline $17-25$ & 57 \\
\hline $26-35$ & 29 \\
\hline $46-55$ & 14 \\
\hline
\end{tabular}

valid dan dapat digunakan untuk penelitian selanjutnya.

\section{Data Demografi}

Berdasarkan jumlah pasien dalam ratarata tiga bulan diambil sampel sebanyak 100 pasien, dengan rincian sebagai berikut:

\section{Dimensi Sikap dan Penampilan}

Berdasarkan hasil analisa data yang diperoleh melalui aplikasi e-servqual terlihat bahwa kepuasan pasien pada dimensi sikap dan penampilan, dengan nilai rata-rata kepuasan pasien sebesar 
$71.88 \%$ dan nilai harapan pasien sebesar 92.56\%, sehingga diperoleh hasil tingkat kepuasan pasien terhadap dimensi sikap dan penampilan sebesar $77.6 \%$ dengan kategori kepuasan cukup.

Tabel VI. Nilai Kepuasan dan Harapan

\begin{tabular}{|c|c|c|c|c|}
\hline No & Pernyataan & Nilai Kepuasan & $\begin{array}{c}\text { Nilai } \\
\text { Harapan }\end{array}$ & $\begin{array}{l}\text { Tingkat } \\
\text { Kepuasan }\end{array}$ \\
\hline 1 & $\begin{array}{l}\text { Petugas terlihat bersih rapih } \\
\text { memakai seragam dan tanda } \\
\text { pengenal }\end{array}$ & $69.40 \%$ & $93.50 \%$ & $\frac{71.88 \%}{92.56 \%}$ \\
\hline 2 & $\begin{array}{l}\text { Pelayanan yang tidak membeda- } \\
\text { bedakan }\end{array}$ & $73.30 \%$ & $92.50 \%$ & \\
\hline 3 & $\begin{array}{l}\text { Pasien datang petugas sigap } \\
\text { melayani }\end{array}$ & $73.90 \%$ & $93.25 \%$ & $=0.776$ \\
\hline 4 & Petugas ramah dan melayani & $70.90 \%$ & $91.00 \%$ & CUKUP \\
\hline \multirow{2}{*}{\multicolumn{2}{|c|}{ Rata-rata }} & \multicolumn{3}{|c|}{$92.56 \%$} \\
\hline & & Puas & $\begin{array}{l}\text { Sangat } \\
\text { Penting }\end{array}$ & \\
\hline \multicolumn{2}{|c|}{$\begin{array}{l}\text { Berdasarkan hasil analisa data yang } \\
\text { diperoleh melalui aplikasi e-servqual } \\
\text { terlihat bahwa kepuasan pasien pada } \\
\text { dimensi keandalan, dengan nilai rata- }\end{array}$} & \multicolumn{3}{|c|}{$\begin{array}{l}92.06 \% \text {, sehingga diperoleh hasil } \\
\text { tingkat kepuasan pasien terhadap } \\
\text { dimensi keandalan sebesar } 78.9 \% \\
\text { dengan kategori kepuasan cukup. }\end{array}$} \\
\hline
\end{tabular}
rata kepuasan pasien sebesar $72.70 \%$

Tabel VII. Nilai Kepuasan dan Harapan

\begin{tabular}{|c|c|c|c|c|}
\hline No & Pernyataan & $\begin{array}{c}\text { Nilai } \\
\text { Kepuasan }\end{array}$ & $\begin{array}{c}\text { Nilai } \\
\text { Harapan }\end{array}$ & $\begin{array}{l}\text { Tingkat } \\
\text { Kepuasan }\end{array}$ \\
\hline 1 & $\begin{array}{l}\text { Kecepatan dan ketelitian petugas } \\
\text { dalam melayani pasien }\end{array}$ & $69.30 \%$ & $90.75 \%$ & $\frac{72.70 \%}{92.06 \%}$ \\
\hline 2 & $\begin{array}{l}\text { Informasi yang diberikan petugas } \\
\text { lengkap dan mudah dimengerti }\end{array}$ & $73.70 \%$ & $92.00 \%$ & \\
\hline 3 & $\begin{array}{l}\text { Petugas melayani dengan tuntas } \\
\text { dan menyeluruh }\end{array}$ & $74.60 \%$ & $92.75 \%$ & $=0.789$ \\
\hline 4 & $\begin{array}{l}\text { Rasa percaya terhadap pelayanan } \\
\text { yang diberikan petugas }\end{array}$ & $73.20 \%$ & $92.75 \%$ & CUKUP \\
\hline \multirow{2}{*}{\multicolumn{2}{|c|}{ Rata-rata }} & $72.70 \%$ & $92.06 \%$ & \\
\hline & & Puas & Penting & \\
\hline
\end{tabular}




\section{Dimensi Waktu Tunggu Resep}

Berdasarkan hasil analisa data yang diperoleh melalui aplikasi e-servqual terlihat bahwa kepuasan pasien pada dimensi waktu tunggu resep, dengan nilai rata-rata kepuasan pasien sebesar
$71.30 \%$ dan nilai harapan pasien sebesar $92.13 \%$, sehingga diperoleh hasil tingkat kepuasan pasien terhadap dimensi waktu tunggu resep sebesar 77,3\% dengan kategori kepuasan cukup.

Tabel VIII. Nilai Kepuasan dan Harapan

\begin{tabular}{clccc}
\hline No & Pernyataan & $\begin{array}{c}\text { Nilai } \\
\text { Kepuasan }\end{array}$ & $\begin{array}{c}\text { Nilai } \\
\text { Harapan }\end{array}$ & $\begin{array}{c}\text { Tingkat } \\
\text { Kepuasan }\end{array}$ \\
\hline 1 & Resep non racikan 5 - 15 menit & $72.50 \%$ & $92.25 \%$ & $\frac{\mathbf{7 1 . 3 0} \%}{\mathbf{9 2 . 1 3} \%}$ \\
\hline 2 & $\begin{array}{l}\text { Resep racikan maksimal 30 } \\
\text { menit }\end{array}$ & $70.10 \%$ & $92.00 \%$ & $=0.773$ \\
\hline
\end{tabular}

\begin{tabular}{cccc}
\hline Rata-rata & $\mathbf{7 1 . 3 0 \%}$ & $\mathbf{9 2 . 1 3 \%}$ & CUKUP \\
\hline & Puas & Penting \\
\hline
\end{tabular}

\section{Dimensi Jaminan}

Berdasarkan hasil analisa data yang diperoleh melalui aplikasi e-servqual terlihat bahwa kepuasan pasien pada dimensi jaminan, dengan nilai rata-rata kepuasan pasien sebesar $72.88 \%$ dan nilai harapan pasien sebesar $87.92 \%$, sehingga diperoleh hasil tingkat kepuasan pasien terhadap dimensi jaminan sebesar $82.8 \% \%$ dengan kategori kepuasan tinggi.

Tabel IX. Nilai Kepuasan dan Harapan

\begin{tabular}{|c|c|c|c|c|}
\hline No & Pernyataan & $\begin{array}{c}\text { Nilai } \\
\text { Kepuasan }\end{array}$ & $\begin{array}{c}\text { Nilai } \\
\text { Harapan }\end{array}$ & $\begin{array}{l}\text { Tingkat } \\
\text { Kepuasan }\end{array}$ \\
\hline 1 & $\begin{array}{l}\text { Petugas memberikan pelayanan yang sesuai } \\
\text { kebutuhan dan keinginan pasien }\end{array}$ & $71.70 \%$ & $92.75 \%$ & $\frac{\mathbf{7 2 . 8 8} \%}{\mathbf{8 7 . 9 2} \%}$ \\
\hline 2 & $\begin{array}{l}\text { Petugas mendengarkan dan menjawab setiap } \\
\text { pertanyaan dan keluhan pasien dengan baik, } \\
\text { jelas dan ramah }\end{array}$ & $74.00 \%$ & $92.75 \%$ & \\
\hline 3 & $\begin{array}{l}\text { Petugas aktif memberikan respon kepada } \\
\text { pasien }\end{array}$ & $72.50 \%$ & $88.50 \%$ & $=0.828$ \\
\hline 4 & $\begin{array}{l}\text { Petugas menawarkan dan memberikan } \\
\text { tambahan informasi yang bermanfaat }\end{array}$ & $73.30 \%$ & $86.19 \%$ & TINGGI \\
\hline \multirow{2}{*}{\multicolumn{2}{|c|}{ Rata-rata }} & $72.88 \%$ & $87.92 \%$ & \\
\hline & & Puas & Penting & \\
\hline
\end{tabular}

\section{Dimensi Empati}


Berdasarkan hasil analisa data yang diperoleh melalui aplikasi e-servqual terlihat bahwa kepuasan pasien pada dimensi empati, dengan nilai rata-rata kepuasan pasien sebesar $70.33 \%$ dan nilai harapan pasien sebesar $92.72 \%$, sehingga diperoleh hasil tingkat kepuasan pasien terhadap dimensi empati sebesar $77,3 \%$ dengan kategori kepuasan cukup.

Tabel X. Nilai Kepuasan dan Harapan

\begin{tabular}{|c|c|c|c|c|}
\hline No & Pernyataan & $\begin{array}{c}\text { Nilai } \\
\text { Kepuasan }\end{array}$ & $\begin{array}{c}\text { Nilai } \\
\text { Harapan }\end{array}$ & $\begin{array}{l}\text { Tingkat } \\
\text { Kepuasan }\end{array}$ \\
\hline 1 & $\begin{array}{l}\text { Petugas menerapkan } 5 \mathrm{~S} \text { (senyum, } \\
\text { salam, sapa, sopan dan santun) dalam } \\
\text { melayani }\end{array}$ & $68.10 \%$ & $92.38 \%$ & $\frac{70.33 \%}{92.72 \%}$ \\
\hline 2 & $\begin{array}{l}\text { Anda puas dengan pelayanan yang } \\
\text { diberikan }\end{array}$ & $65.90 \%$ & $93.25 \%$ & $=0.773$ \\
\hline \multirow[t]{2}{*}{3} & $\begin{array}{l}\text { Ketersediaan atau kelengkapan obat } \\
\text { yang diberikan }\end{array}$ & $72.70 \%$ & $92.25 \%$ & \\
\hline & & & & CUKUP \\
\hline \multirow[t]{3}{*}{4} & $\begin{array}{l}\text { Petugas kompeten dalam melayani } \\
\text { pasien }\end{array}$ & $74.60 \%$ & $93.00 \%$ & \\
\hline & Rata-rata & $70.33 \%$ & $92.72 \%$ & \\
\hline & & Puas & $\begin{array}{l}\text { Sangat } \\
\text { Penting }\end{array}$ & \\
\hline
\end{tabular}

\section{Dimensi Sarana dan Fasilitas}

Berdasarkan hasil analisa data yang diperoleh melalui aplikasi e-servqual terlihat bahwa kepuasan pasien pada dimensi sarana dan fasilitas, dengan nilai rata-rata kepuasan pasien sebesar
$72.20 \%$ dan nilai harapan pasien sebesar $81.13 \%$, sehingga diperoleh hasil tingkat kepuasan pasien terhadap dimensi sarana dan fasilitas sebesar 88.9\% dengan kategori kepuasan tinggi

Tabel XI. Nilai Kepuasan dan Harapan

\begin{tabular}{lllll}
\hline No & \multicolumn{1}{c}{ Pernyataan } & $\begin{array}{c}\text { Nilai } \\
\text { Kepuasan }\end{array}$ & $\begin{array}{c}\text { Nilai } \\
\text { Harapan }\end{array}$ & $\begin{array}{c}\text { Tingkat } \\
\text { Kepuasan }\end{array}$ \\
\hline 1 & Bangunan terlihat bagus dan rapih & $71.50 \%$ & $81.50 \%$ & \\
\hline 2 & $\begin{array}{l}\text { Ruang tunggu nyaman, bersih, rapih } \\
\text { dan harum }\end{array}$ & $72.60 \%$ & $81.25 \%$ & $\underline{\mathbf{8 1 . 1 3} \%}$ \\
\hline
\end{tabular}




\begin{tabular}{|c|c|c|c|c|}
\hline 3 & $\begin{array}{l}\text { Terdapat sarana hiburan seperti televisi } \\
\text { dan buku bacaan }\end{array}$ & $72.70 \%$ & $81.00 \%$ & $=0.889$ \\
\hline 4 & $\begin{array}{l}\text { Adanya fasilitas penunjang seperti } \\
\text { kursi roda dan ruang khusus }\end{array}$ & $72.00 \%$ & $80.75 \%$ & TINGGI \\
\hline & Rata-rata & $\begin{array}{l}72.20 \% \\
\text { Puas }\end{array}$ & $\begin{array}{l}\text { 81.13\% } \\
\text { Penting }\end{array}$ & \\
\hline
\end{tabular}

\section{Analisis Kesenjangan (Gap)}

Berdasarkan hasil analisis kesenjangan, maka dapat diketahui bahwa rata-rata tingkat kepuasan masih berada dibawah rata-rata tingkat harapan pasien. Beberapa dimensi yang berada di atas rata-rata selisih merupakan dimensi yang perlu diprioritaskan untuk diperbaiki (Tabel 4). Dimensi yang perlu diprioritaskan dari hasil penelitian ini adalah waktu tunggu resep dengan nilai selisih antara nilai harapan dengan kepuasan sebesar $20.83 \%$. Selain waktu tunggu resep dalam hal ini sikap dan penampilan memiliki tingkat harapan sebesar $92.56 \%$ dengan kepuasan yang dirasakan pasien sebesar $71.88 \%$, maka terdapat selisih sebesar $20.68 \%$.

Tabel XII. Nilai selisih antara harapan dan persepsi kepuasan

\begin{tabular}{llccc}
\hline No & \multicolumn{1}{c}{ Pernyataan } & Nilai Kepuasan & $\begin{array}{c}\text { Nilai } \\
\text { Kepentingan }\end{array}$ & Selisih \\
\hline 1 & Sikap dan Penampilan & $71.88 \%$ & $92.56 \%$ & $20.68 \%$ \\
\hline 2 & Keandalan & $72.70 \%$ & $92.06 \%$ & $19.36 \%$ \\
\hline 3 & Waktu Tunggu Resep & $71.30 \%$ & $92.13 \%$ & $20.83 \%$ \\
\hline 4 & Jaminan & $72.88 \%$ & $92.72 \%$ & $19.84 \%$ \\
\hline 5 & Empati & $70.33 \%$ & $87.92 \%$ & $17.59 \%$ \\
\hline 6 & Sarana dan Fasilitas & $72.20 \%$ & $81.13 \%$ & $8.93 \%$ \\
\hline \multicolumn{4}{c}{ Rata-rata } & $\mathbf{7 1 . 8 8 \%}$ \\
\hline
\end{tabular}

\section{Diagram Cartesius}

Diagram Cartesius menggambarkan dimensi-dimensi yang mempengaruhi kepuasan konsumen. Perhitungan awal yang dilakukan untuk penempatan, dimensi-dimensi yang dianggap penting oleh pasien.

Penjelasan dari masing-masing kuadran:

a. Kuadran I. Dimensi yang dianggap mempengaruhi kepuasan pasien, termasuk unsur-unsur jasa yang dianggap sangat penting namun belum sesuai keinginan.

b. Kuadran II Unsur yang telah berhasil dilaksanakan, sehingga wajib dipertahankan karena dianggap penting dan sangat memuaskan pelanggan.

c. Kuadran III Faktor yang kurang penting pengaruhnya bagi pasien, 
dianggap kurang penting dan kurang memuaskan pasien.

d. Kuadran IV Faktor yang kurang penting bagi pasien tetapi pelaksanaannya berlebihan atau dianggap kurang penting sangat memuaskan pasien (Cronin dan Taylor, 1994)

Berdasarkan hasil diagram cartesius antara tingkat kepuasan dengan tingkat kepentingan pada penelitian ini terlihat bahwa ada tiga dimensi yang berada di kuadran II yang termasuk kategori yang harus dipertahankan. Sementara ada dua dimensi yang berada di kuadran II yang termasuk dalam kategori yang dianggap penting oleh pasien. Serta terdapat 1 dimensi yang termasuk dalam kategori yang dirasa kurang penting bagi pasien.

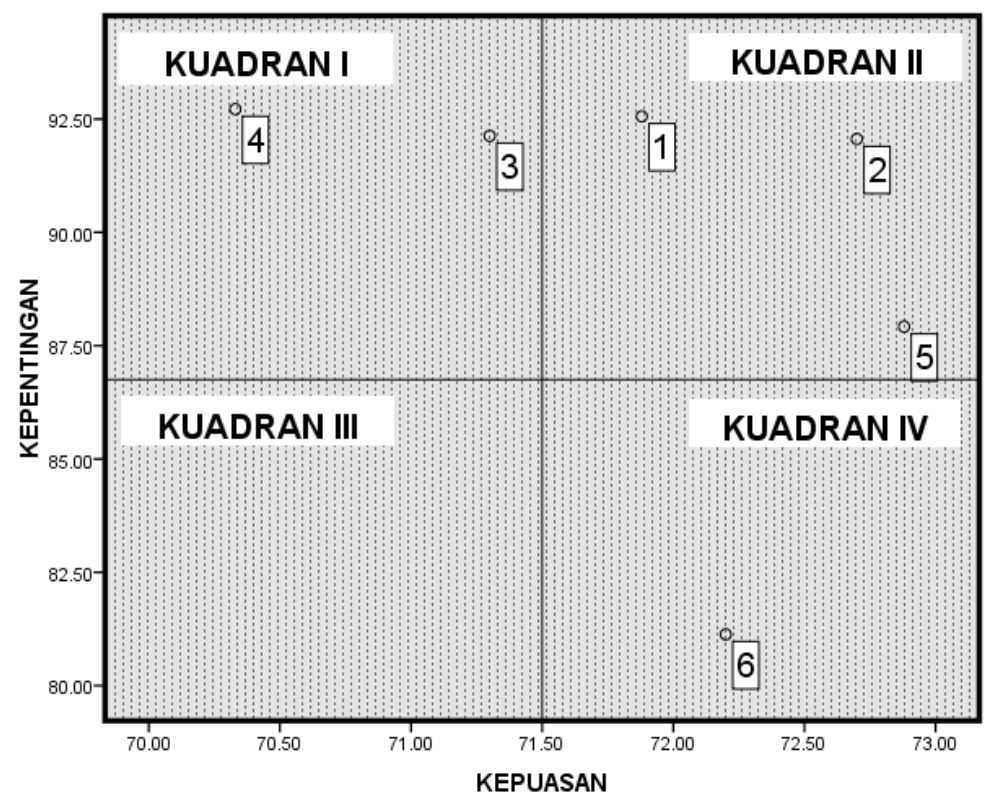

Gambar 3. Diagram Cartesius Hasil Penelitian

\section{SIMPULAN}

Berdasarkan hasil penelitian dapat disimpulkan bahwa tingkat kepuasan pasien terhadap pelayanan kefarmasian yang dilihat pada enam dimensi dengan menggunakan aplikasi e-servqual dirancang secara khusus untuk dapat menerima dan merekap jawaban dari kuisioner yang telah diisi oleh pasien, diperoleh hasil bahwa dimensi keandalan, waktu tunggu resep, empati serta sarana dan fasilitas dirasa penting untuk diperhatikan. Selain itu untuk dimensi jaminan dan sikap \& penampilan dirasa sangat penting untuk menjadi prioritas dalam pelayanan kefarmasian di Klinik X.

\section{SARAN}

Saran dari penelitian ini adalah:

a. Hasil penelitian dapat dijadikan acuan untuk evaluasi klinik X.

b. Dilakukan penelitian lanjutan tentang kualitas pelayanan dari dimensi yang lain seperti menggunakan metode 
accidental sehingga gambaran tingkat kepuasannya lebih luas.

\section{UCAPAN TERIMA KASIH}

Pada kesempatan ini, peneliti ingin mengucapkan terima kasih kepada berbagai pihak yang telah membantu terwujudnya penelitian ini :

1. Yayasan Pendidikan IKIFA yang telah mendanai dan memfasilitasi penelitian ini.

2. Unit Penelitian dan Pengabdian Masyarakat Akademi Farmasi IKIFA

\section{DAFTAR PUSTAKA}

Musran Munizu, Jurnal Manajemen dan Kewirausahaan Vol.13 No.2, 185194

Satya Enti Rikomah. 2016. Farmasi Klinik Edisi I halaman 18-19.

Republik Indonesia,. 2014. Keputusan Menteri Kesehatan Republik Indonesia Nomer 1027.

Peraturan Pemerintah Nomor 51 Tahun 2009 tentang Pekerjaan Kefarmasian. Jakarta ;Departemen Kesehatan Republik Indonesia; 2009.

Tjiptono, Fandy, Ph.D. 2016 Service Quality and Satisfaction edisi IV .Yogyakarta. Andi. halaman 162163.

Peraturan Menteri Kesehatan No.9 tahun 2014 tentang Klinik.

Sangadji Etta, M.Si . 2013. Perilaku Konsumen Edisi 1. Yogyakarta. Andi halaman 100-101.

Rustianti ninik, S.T.P.,M.Si. 2015. Buku Ajar Ekonomi Pangan dan Gizi. Yogyakarta. Deepubish. halaman 34
Sunyoto danang, S.H.,S.E., MM. 2015. Konsep Dasar Riset Pemasaran dan Perilaku Konsumen. Jakarta. Gramedia. Halaman 102-103.

Riduwan, M.B.A. Belajar Mudah Penelitian. Alfabeta; 2011 halaman 65

Echtar Saban, S.E., M.Si,. 2017 Metode Penelitian Manajemen dan Bisnis. Bogor. Ghalia Indonesia. Halaman

Sugiarto, Endar. 1999. Psikologi Pelayanan dalam Industri Jasa,.Jakarta: Graniedia Pustaka Utama

Supranto. 2001. Pengukuran Kepuasan Pelanggan. Jakarta : PT. Rineka Cipta.

Supriyanto, Yuda dan Harry Seosanto. 2012. Analisis Pengaruh Kualitas Pelayanan, Harga, Dan Fasilitas Terhadap Kepuasan Pasien Rawat Jalan Di Rumah Sakit Kariadi Semarang. Diponegoro Journal of Management. Volume 1. Nomor 1 (http://ejournals1.undip.ac.id/index.php/dbr, diakses 26 Januari 2012).

Surjandari, Isti dan Beatricia Pahlevi Thamarica. 2009. Integrating Multivariate Method and Quality Function Deployment to Analyze in Patient Satisfaction. Jurnal Manajemen Pelayanan Kesehatan. Volume 12. Nomor 02 (http://isjd.pdii.lipi.go.id/admin/ju rnal/122096873.pdf, diakses 26 Januari 2013).

Tiro, M. A dan Arbianingsih. 2011. Teknik Pengambilan Sampel. Makassar: Andira Publisher. 
Tiro, M. A dan Nur Hidayah. 2012. Metode Penelitian Sosial. Makassar: Andira Publisher.

Irawan, Handi. 2003. Indonesian Customer Satisfaction. Jakarta: PT. Alex Media Computindo.

Junaidi. 2009. Indikator Pemanfaatan Fasilitas. In http://repository.ac.id. Diakses 25 Mei 2013.

Hariyanto, Khasanah N, Supardi S. Kepuasan Pasien Terhadap Pelayanan Resep di Apotek KopKar Rumah Sakit Budi Asih Jakarta. Majalah Ilmu Kefarmasian. 2005;Vol.2:12-21.

Kadir, A., 2009, Membuat Aplikasi

Web dengan PHP dan Database MySQL, Andi, Yogyakarta. 